University of Nebraska - Lincoln

DigitalCommons@University of Nebraska - Lincoln

$12-2011$

\title{
Spring Migration of Mallards from Arkansas as Determined by Satellite Telemetry
}

David George Krementz

Kwasi Asante

Luke W. Naylor

Follow this and additional works at: https://digitalcommons.unl.edu/usgsstaffpub

Part of the Geology Commons, Oceanography and Atmospheric Sciences and Meteorology Commons, Other Earth Sciences Commons, and the Other Environmental Sciences Commons

This Article is brought to you for free and open access by the US Geological Survey at DigitalCommons@University of Nebraska - Lincoln. It has been accepted for inclusion in USGS Staff -- Published Research by an authorized administrator of DigitalCommons@University of Nebraska - Lincoln. 


\title{
Articles \\ Spring Migration of Mallards from Arkansas as Determined by Satellite Telemetry
}

\author{
David G. Krementz,* Kwasi Asante, Luke W. Naylor
}

\section{D.G. Krementz}

U.S. Geological Survey Arkansas Cooperative Fish and Wildlife Research Unit, Department of Biological Sciences, 1 University of Arkansas, Fayetteville, Arkansas 72701

\section{K. Asante}

Department of Geosciences, 1 University of Arkansas, Fayetteville, Arkansas 72701

\section{L.W. Naylor}

Arkansas Game and Fish Commission, 2 Natural Resources Drive, Little Rock, Arkansas 72205

\begin{abstract}
We used satellite telemetry to document spring migration phenology, routes, stopover regions, and nesting sites of mallards Anas platyrhynchos marked in Arkansas during the winters of 2004-2007. Of the 143 marked mallards that migrated from Arkansas, they did so, on average, by mid-March. Mallards flew over the Missouri Ozarks and $42 \%$ made an initial stopover in Missouri, where they used areas that had larger rivers (Mississippi River, Missouri River) embedded in an agricultural landscape. From this stopover region they either migrated directly to the Prairie Pothole Region (PPR) or they migrated north to Minnesota where they either moved next to the PPR or to the north and east of the PPR. For those mallards (83\%) that stopped for $>1 \mathrm{~d}$ before entering the PPR, the average length at each stop was $12 \mathrm{~d}$ (SE $=0.90 \mathrm{~d}$, range $=2-54 \mathrm{~d}$ ). Mallards made more stopovers, made shorter migration movements, and took longer to move to the PPR in wetter than drier years. Mallards arrived in the PPR earlier in 2006 ( $\bar{x}=30$ March, SE $=2.18 \mathrm{~d})$ than in $2005(\bar{x}=7$ April, SE $=2.30 \mathrm{~d}$ ). Females nested across nine Bird Conservation Regions. Nesting occurred most frequently in South Dakota $(n=9)$. The average date when females nested was 19 April (SE = $2.44 \mathrm{~d}$, range $=12$ March-26 May). Because many mallards headed for the large river corridors in Missouri for their first stopover, this region is an important spring migration stopover of continental importance to mallards and might be considered a focal area for conservation.
\end{abstract}

Keywords: Anas platyrhynchos; mallard; migration; movements; satellite telemetry

Received: April 5, 2011; Accepted: September 5, 2011; Published Online Early: September 2011; Published: December 2011

Citation: Citation: Krementz DG, Asante K, Naylor LW. 2011. Spring migration of mallards from Arkansas as determined by satellite telemetry. Journal of Fish and Wildlife Management 2(2):156-168; e1944-687X. doi: 10.3996/042011-JFWM026

Copyright: All material appearing in the Journal of Fish and Wildlife Management is in the public domain and may be reproduced or copied without permission unless specifically noted with the copyright symbol (C). Citation of the source, as given above, is requested.

The findings and conclusions in this article are those of the author(s) and do not necessarily represent the views of the U.S. Fish and Wildlife Service.

* Corresponding author: krementz@uark.edu

\section{Introduction}

The mallard Anas platyrhynchos is the most abundant, most sought-after, and most harvested duck species in North America (Drilling et al. 2002). Due to their recreational harvest importance, most waterfowl management by the Canadian Wildlife Service and U.S. Fish and Wildlife Service is based on the mallard (Sparrowe and Patterson 1987; Johnson et al. 1997). Because of the desire to optimally manage the mallard population, the species is probably the most studied bird in the world. Mallard migration studies have been based on subjective migration surveys (Bellrose et al. 1961; Bellrose 1980), analyses of hunter-reported harvests and band recoveries (Green and Krementz 2008), conventional VHF radiotelemetry (Dugger 1997), and satellite transmitters (platform 
transmitter terminals [PTTs]) in Japan (Yamaguchi et al. 2008). These studies have provided information about the timing, routes, and behavior of mallards during spring migration (Drilling et al. 2002). Despite these studies on spring migration biology of mallards, many questions remain, in part because of the lack of technology available to answer those questions (Yamaguchi et al. 2008). However, advances in PTT technology now provide biologists with the opportunity to conduct large-scale studies of smaller body sized birds, like the mallard, using satellite telemetry (Yamaguchi et al. 2008; Roshier and Asmus 2009).

Information on timing, length, and duration of spring migration for mallards and other waterfowl is needed for development of conservation plans. In the Lower Mississippi Valley Joint Venture, which is a partnership established under the North American Waterfowl Management Plan to conserve the continent's waterfowl populations and habitats, the waterfowl working group uses spring waterfowl migration timing to estimate the population size from which habitat objectives are calculated (J. Tirpak, U.S. Fish and Wildlife Service, personal communication). In the Upper Mississippi River and Great Lakes Joint Venture planning document (JV 2007), "spring migration habitat was assumed to be more limiting then fall, thus the "population bottleneck" for migration habitat planning." (JV 2007). In this plan, the mallard was chosen as a "focal species" on which planning for puddle ducks would be primarily based. The planning document (JV 2007) conceded that information gaps for mallard spring migration biology still existed and warranted further research. Examples of information needed include: migration corridor identification, duration of stay at stopover locations, and total nonbreeding use days in the region (JV 2007).

Nutrient acquisition during spring migration has the potential to affect subsequent reproductive success in waterfowl (Heitmeyer and Fredrickson 1981; Kaminski and Gluesing 1987; Raveling and Heitmeyer 1989; Devries et al. 2008). Female ducks in better condition on reaching the breeding grounds have a higher propensity to breed (Alisauskas and Ankney 1992), have an earlier onset of laying (Dubovsky and Kaminski 1994), have an increased clutch size (Krapu 1981), and are more able to lay another clutch if a nest is destroyed (Arnold et al. 2002). Hence, knowledge of where mallards are migrating and staging during spring can assist managers in focusing wetland management in the correct areas.

We were interested in sex-specific variation in these variables because although most mallards are paired by the beginning of spring migration (Rohwer and Anderson 1988), Humburg et al. (1978) found that up to $20 \%$ of drakes arriving in lowa were initially not paired; thus, migration movements and patterns may vary by sex. Drilling et al. (2002) recognized that, in addition to sex-specific variation in spring migration movements, other sources of variation in spring migration movements and timing existed. Information on migration patterns from spring departure to arrival on their breeding grounds gathered by following individual birds is fundamental to directing conservation strategies for the mallard. Ultimately, knowledge of individual variation in migration strategies can be used to model time-energy trade-offs in mallard migration (Dugger 1997; Farmer and Wiens 1999). With more precise information concerning mallard spring migration biology, managers can make more informed decisions about spring habitat management for mallards. Such information also can facilitate development and refinement of population conservation objectives for mallards associated with North American Waterfowl Management Plan activities (North American Waterfowl Management Plan Assessment Steering Committee 2007). Our objective was to use satellite telemetry to characterize migration of mallards from Arkansas during the springs of 20042007. Specifically, we 1) documented the routes and timing of spring migration, 2) identified major springmigration stopover regions, 3 ) estimated length of stay at stopovers, and 4) investigated sex-, year-, and sex $\times$ year-specific variation for those variables. Additionally, we assessed whether migration patterns varied with respect to annual weather conditions across the spring migration corridor.

\section{Study Area}

Our study area included all mallard satellite locations outside of Arkansas (Figure 1), which included the midcontinent region of North America. Bellrose (1980) documented that the two most important migration corridors for mallards wintering in the Lower Mississippi Alluvial Valley were through western and eastern Missouri, and from there, mallards traveled northwest to the Prairie Pothole Region (PPR; Mann 1974). The PPR is where most mallards (approx. 75\%) that winter in Arkansas were produced (Munro and Kimball 1982; Supplemental Material, Reference S1; http://dx.doi.org/ 10.3996/042011-JFWM-026.S1). We characterized the weather for the 10 states north of Arkansas through which marked mallards migrated using the temperature and precipitation ranks (NCDC 2011) during the spring months of March-May. We found that over the study period these ranks ranged from near normal to much above normal for temperature and much below to record-wettest precipitation (Table 1). In 2005 temperature ranks were mostly above normal, while in the other years temperature ranks were mostly much above normal. We found that precipitation ranks were more variable, with 2004 being wetter, 2005 being drier, 2006 being normal, and 2007 being much wetter. Therefore, we characterized our study years relative to the 18952011 period as 2004 being warmer and wetter, 2005 as warm and dry, 2006 as warmer and normal precipitation, and 2007 as warmer and much wetter. We captured mallards on 14 public and private managed seasonal wetlands in Arkansas: 9 sites in the Mississippi Alluvial Valley portion of Arkansas ("Delta") where the land use was predominantly row crops, 3 sites in the Arkansas River Valley where the land use was predominantly pasturelands, and 2 sites in the West Gulf Coastal Plain 


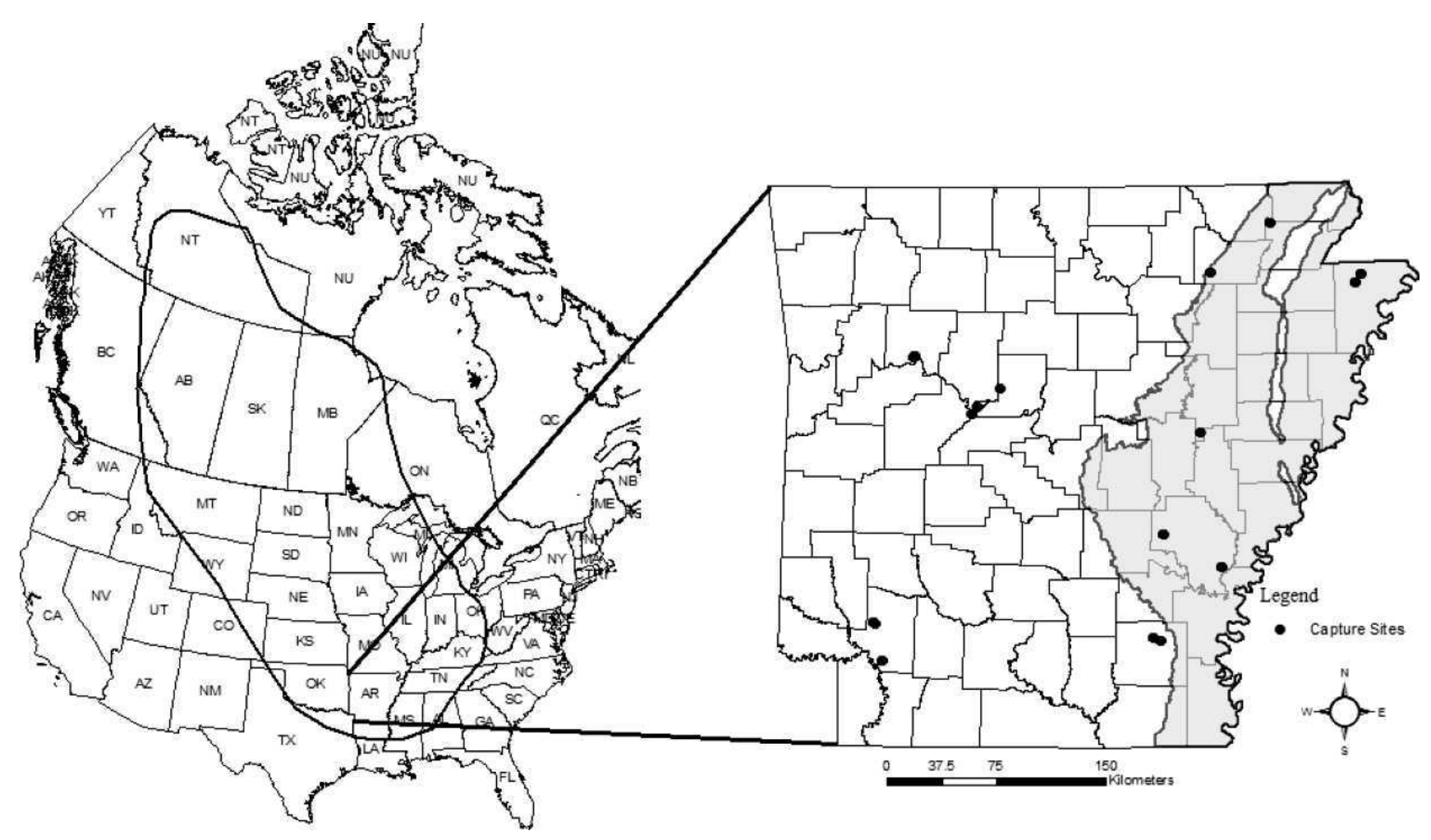

Figure 1. Sites in Arkansas (right-hand panel) where mallards Anas platyrhynchos were captured. The shaded region in Arkansas demarcates the lower Mississippi Alluvial Valley region ("Delta").The polygon overlay on the map of North America (left-hand panel) designates the outer boundary surrounding all mallard satellite locations that we used for determining spring migration locations from 2004 to 2007.

where the land use was predominantly pasturelands and forestlands (GAP/LULC 2007; Figure 1).

\section{Methods}

We captured mallards during 1) February and March 2004, 2) February 2005, 3) January, February, March, November, and December 2006, and 4) January and February 2007. We attracted mallards to baited stations and captured birds using rocket nets (Wunz 1984) or swim-in traps (Evrard and Bacon 1998). We tagged both male and female mallards during 2004-2006 and only females in 2007. We attached a federal leg band to each captured mallard. In 2007 only, we recorded the body mass (g) of each captured mallard. We used two types of
PTTs from Microwave Telemetry, Inc. (Columbia, MD), battery- or solar-powered. In 2004 and 2005, all PTTs were battery-powered; while in 2006 and 2007, we used both battery- and solar-powered PTTs. Duty cycles for PTTs were adjusted over the course of the study to maximize data collection during the spring migration period (1 February-31 May) and conserve battery life (Table 2). During the summer, the duty cycle was constant across years (1 June-31 August: $6 \mathrm{~h}$ on, $240 \mathrm{~h}$ off). With the exception of a single PTT in 2007, all units were only active during diurnal periods. The units, with harness and protective neoprene pad, weighed between 22-35 g. For all mallards captured in 2007, the PTT weighed about $2 \%$ of average body mass at capture $(1,098 \mathrm{~g}, \mathrm{SE}=9.84)$, which was under the $3 \%$ of body

Table 1. Temperature and precipitation ranks ${ }^{a}$ for March-May 2004-2007 in 10 states through which marked mallards Anas platyrhynchos migrated during the spring. States included Illinois, lowa, Kansas, Michigan, Minnesota, Missouri, Nebraska, North Dakota, South Dakota, and Wisconsin.

\begin{tabular}{lll}
\hline Year & \multicolumn{1}{c}{ Temperature rank } & \multicolumn{1}{c}{ Precipitation rank } \\
\hline 2004 & Above normal (4), much above normal (6) & Near normal (2), above normal (5), much above normal (2), record wettest (1) \\
2005 & Near normal (4), above normal (6) & Much below normal (4), below normal (1), near normal (3), above normal (2) \\
2006 & Above normal (4), much above normal (6) & Below normal (1), near normal (6), above normal (3) \\
2007 & Above normal (4), much above normal (6) & Below normal (1), near normal (3), above normal (1), much above normal (5) \\
\hline
\end{tabular}

${ }^{a}$ Ranks are based on a 117-y period (1895-2011) with much below normal falling into the bottom 12 periods, below normal falling into the next 39 periods, near normal falling into the middle 39 periods, above normal falling into the 39 higher periods, much above normal falling into the top 12 periods, and record wettest being the wettest ever recorded (National Climatic Data Center 2011).

${ }^{b}$ Number of states out of 10 states with that rank for that year. 
Table 2. February to May duty cycles of satellite transmitters deployed on mallards Anas platyrhynchos marked in Arkansas between 2004 and 2007.

\begin{tabular}{cccc}
\hline & \multicolumn{4}{c}{ Duty cycle } \\
\cline { 2 - 4 } Year & $\begin{array}{c}\mathbf{6} \text { h on, } \\
\mathbf{4 8} \text { h off }\end{array}$ & $\begin{array}{c}\mathbf{1 0} \text { h on, } \\
\mathbf{2 4} \text { h off }\end{array}$ & $\begin{array}{c}\text { Four readings/d (0800, } \\
\mathbf{1 2 0 0}, \mathbf{1 6 0 0 ,} \text { 2000 hours) }\end{array}$ \\
\hline 2004 & 23 & - & - \\
2005 & 41 & - & - \\
2006 & 41 & 4 & - \\
2007 & 5 & 28 & 1 \\
\hline
\end{tabular}

mass recommended guidelines for transmitter mass by the U.S. Geological Survey Bird Banding Laboratory (http://www.pwrc.usgs.gov/BBL/). We suspect that the PTTs were a similar percent of body mass in the other years. We attached each PTT dorsally between the wings by fashioning a harness of $0.38-\mathrm{cm}$-wide (sold as $3 / 16$ in.) Teflon ribbon (Bally Ribbon, Bally, PA). The completed harness included fore and aft body loops connected with a 1-cm length of ribbon over the keel (Figure 2; Petrie et al. 1996; Malecki et al. 2001). We held marked birds for adjustment to the harness and released them diurnally at the site of capture within $24 \mathrm{~h}$ after capture.

We tracked marked mallards until they died or we lost track of the PTT. When this occurred, we categorized a mallard as dead if it remained at the same location for more than two consecutive duty cycles, assuming that the on-board activity counter in the PTT indicated no movement of the PTT during that time. If we lost complete contact with the PTT within the expected lifespan of its power source, we categorized the PTT as censored. All other PTT locations were considered to be from living birds.

Defining the end of spring migration was not precisely possible because we could not conclusively determine when a female began nesting. We dealt with this problem in two ways. First, band recovery analyses indicates that the PPR is a major source of mallards (approx. 75\%) wintering in Arkansas (Munro and Kimball 1982; Supplemental Material, Reference S1; http://dx.doi. org/10.3996/042011-JFWM-026.S1). Once in the PPR, we suspected that female mallards would initiate nesting at some future date. Thus, for those mallards that migrated to the PPR (both males and females), we used the date the mallard first was located in the PPR as one measurement of the end of spring migration. For those few birds that did not migrate to the PPR, we could not objectively define a similar end of spring migration. In a second approach, we monitored all females that migrated from Arkansas until those birds remained in a single location north of the southernmost boundary of the PPR (approx. N $41^{\circ} 15^{\prime}$ ) for $\geq 30 \mathrm{~d}$. At this location, we categorized the female as nesting. We chose $30 \mathrm{~d}$ because this period slightly exceeds the incubation period of mallards (Drilling et al. 2002), and this 30-d definition was used by Miller et al. (2005) and Yamaguchi et al. (2008) to describe possible nesting for satellitemarked northern pintails $A$. acuta and mallards, respectively. This definition underestimates the true number of nesting attempts because many nesting attempts fail before $30 \mathrm{~d}$ (Drilling et al. 2002).

We used the Collecte Localisation Satellites (CLSArgos) location and data collection system (CLS 2008) to monitor tagged mallard movements. Calculated location classes for each PTT were categorized as 3, 2,

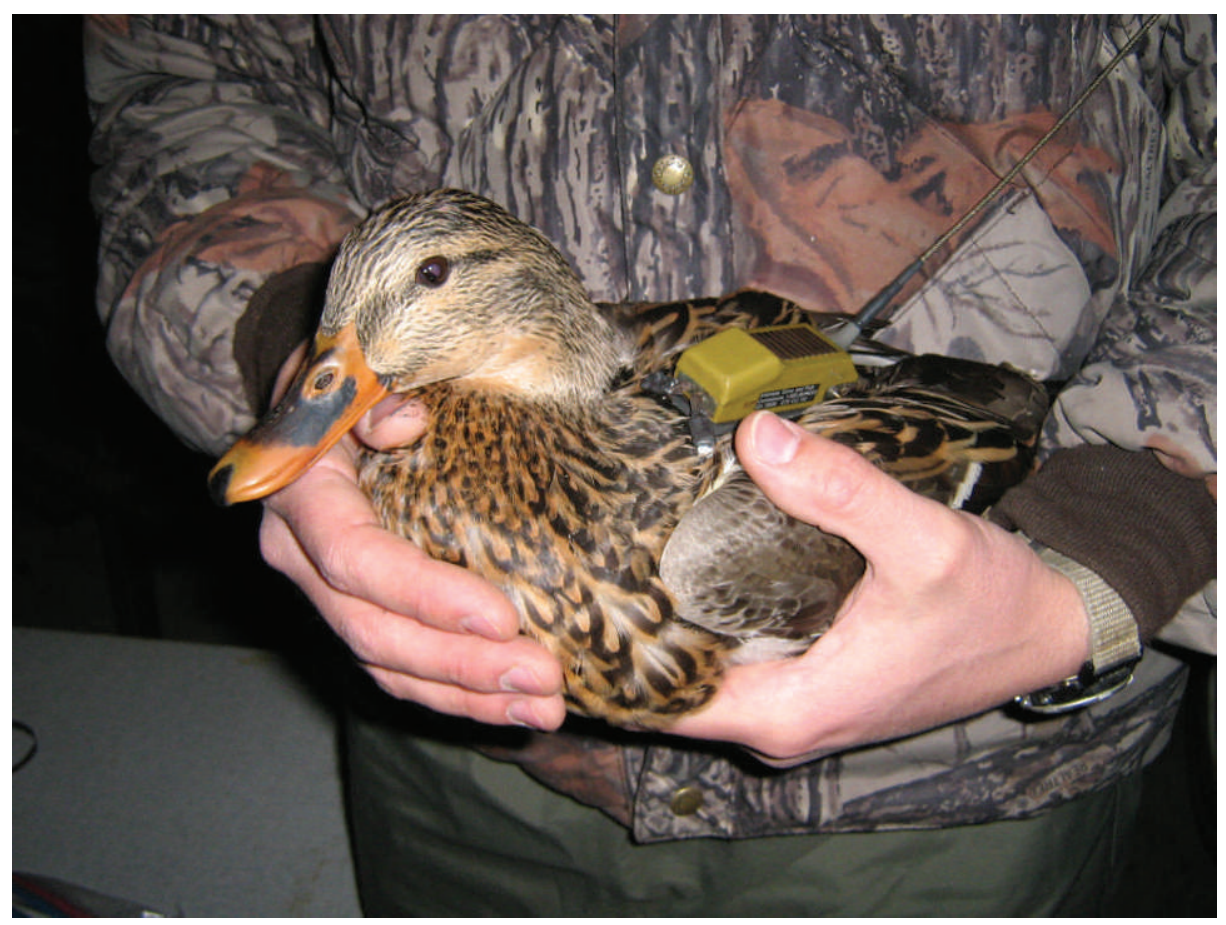

Figure 2. Female mallard captured in Arkansas marked with a satellite transmitter ready for release. 
1 , and 0 , which had accuracies rated as $<150 \mathrm{~m}, 150-$ $350 \mathrm{~m}, 350-1,000 \mathrm{~m}$, and $>1,000 \mathrm{~m}$, respectively. Our most frequent class was the 0 class ( $n=387$ records) followed by class 1 ( $n=158)$, class $2(n=52)$ and class $3(n=39)$. The accuracy of class 0 was not of special concern, however, because mallards moved around $1,000 \mathrm{~km}$ during migration (see below, Yamaguchi et al. 2008); thus, location errors of $<10 \mathrm{~km}$ were negligible. To deal with location errors, we used exclusion rules (Kenow et al. 2002; Miller et al. 2005; Mclntyre et al. 2008). We retained at least one location per duty cycle for each individual, based on the rate of movement between location fixes, the angle of movement in relation to adjacent fixes, the proximity to previous and subsequent locations, the location derived from the most transmissions, and the location class value.

\section{Data analyses}

We documented 1) departure dates from Arkansas, 2) numbers of stops en route as well as the number of days when a bird remained at a single location for more than one duty cycle, 3) number of days on migration to the PPR or to the beginning of "nesting," 4) length of migration "legs" and total distance traveled on migration, 5) end migration date for females "nesting," and 6) their final locations. First, we defined the start of migration as the Julian Day (Julian Day $1=1$ January) that a marked mallard was last located in Arkansas and the subsequent location was outside of Arkansas. Once migration began, we selected from all mallard locations falling into two categories: 1) being located at a single location for one duty cycle (hereafter termed a "single"), or 2) remaining at a single location for more than one duty cycle (hereafter termed a "stopover"). We defined a single location as a mallard that remained in a location for one duty cycle with movements $<8 \mathrm{~km}$. We examined the frequency histogram of distances $(\mathrm{km})$ moved within a duty cycle for five random females each year and found that $>75 \%$ of movements were $<8 \mathrm{~km}$. Note that within an $8-\mathrm{km}$ radius, multiple observations often were recorded. We randomly selected one of the available locations on which to base our movement data. Following this protocol, the total number of locations we used for the above six questions was reduced from 17,379 to 636 locations. We used ArcView GIS 9.3 (Environmental Systems Research Institute, Inc. Redlands, CA) to analyze and plot locations to delineate movements. Based on the best location, we calculated the distance $(\mathrm{m})$ of each vector formed by two consecutive locations (hereafter termed a "leg"). Hence, the migratory journey for each individual was represented as a series of legs connecting the best locations per duty cycle. These movements represent average daily progress across the landscape, as opposed to in-flight speed. We never recorded any within-duty-cycle unidirectional migration movements. We did record cases where a mallard was last in Arkansas and was next located in the PPR (see below). Note, however, that because of the duty cycle (up to $48 \mathrm{~h}$ off), these mallards could have made one or more stops between Arkansas and the PPR.
To analyze these data, we used two basic approaches. First, for comparisons involving dates or distances moved, we tested the effects of: sex, year and sex $\times$ year interaction. For these analyses, we could only use the 2004-2006 data because there were no males marked in 2007. For tests comparing data across 20042007, we only examined females. Using Program JMP 9.0.0 (SAS Institute, Inc. 2010), we used a 2-way factorial analysis of variance (ANOVA) to test main effects. If the year effect was significant $(\alpha=0$. 05), we then conducted a post-ANOVA pair-wise comparison using a Tukey's Honestly Significant Difference test to determine which years were different. Our measure of significance for the Tukey's Honestly Significant Difference test was based on the studentized range statistic (" $Q$ ") when two or more comparisons were made and for single comparisons we used the F-statistic. We present the mean for those variables. Second, for comparisons involving the numbers of single versus stopover events during migration, we used likelihood ratio tests to examine main effects and then present odds ratio to report the direction of significant results.

To examine the distribution of mallards during spring migration, we used ArcGIS 9.3 (Environmental Systems Research Institute) to query, analyze, and map spring migration locations of all mallard locations and those locations focused on the region between Arkansas and the southern latitude of the PPR because we knew that all mallards in this region were on migration, whereas once they entered the PPR their status was unknown (i.e., movements in the PPR or north of there could have been movements related to breeding as well as migration). We calculated $50 \%$ and $95 \%$ kernel density estimates using fixed-kernel estimation, which assumes a random sample and independence of points (Worton 1989). We used least-squares cross-validation to determine smoothing factors in the fixed-kernel estimation procedure because least-squares cross-validation is less biased and performs better than other methods, especially with sample sizes $>50$ (Seaman and Powell 1996; Seaman et al. 1999). Kernel methods are also less sensitive to autocorrelation with the data than are other home-range estimators (Swihart and Slade 1997; de Solla et al. 1999). We used a pixel cell size of $100 \times 100(0.026 \mathrm{~m} \times 0.026 \mathrm{~m})$ with a 100,000-m search radius to conduct the analysis. We violated the independence of points assumption, but offer that our intention here was to describe spring concentration areas of mallards rather than predict where mallard spring concentration areas will be in the future. We finally classified each kernel density estimate into 5 categories based on the Jenks (1967) natural breaks algorithm.

\section{Results}

We marked 108 mallards (30 M:78 F) in the Delta and 72 elsewhere (16 M:56 F; Figure 1). Most mallards were trapped in February (134 [74\%]) with the remainder being trapped in January (17 [9\%]), March (18 [10\%]), November (9[5\%]), and December (2 [1\%]). Of these, 143 migrated from Arkansas (Table 3). Of the 37 mallards that did not migrate away from Arkansas, 16 died and 21 were 
Table 3. Numbers of mallards Anas platyrhynchos (by sex) marked with satellite transmitters in Arkansas, and that subsequently left Arkansas on spring migration between 2004 and 2007.

\begin{tabular}{llcc}
\hline Year & Sex & Marked & Migrated \\
\hline 2004 & Female & 18 & 13 \\
& Male & 10 & 10 \\
2005 & Female & 32 & 26 \\
& Male & 21 & $15^{\mathrm{a}}$ \\
2006 & Female & 35 & $29^{\mathrm{b}}$ \\
& Male & 15 & $16^{\mathrm{c}}$ \\
\hline & Female & 49 & $34^{\mathrm{d}}$ \\
\hline
\end{tabular}

a One male was marked in 2004.

${ }^{\mathrm{b}}$ One female was marked in 2005.

c Two males were marked in 2005.

${ }^{d}$ Four females were marked in 2006.

censored. Technical difficulties precluded regular tracking of most PTTs. Most mallards that left Arkansas were only tracked for a single spring $(n=135)$; however, there were eight mallards tracked in more than one spring (Table 3 ).

Contingent on the date of capture $(10 \%$ of mallards were caught in March), the mean date on which a marked mallard was last located in Arkansas was 19 March $(S D=12.1 \mathrm{~d}$ ) with a range from 18 February to 20 April (Supplemental Material, Table S1; http://dx.doi.org/ 10.3996/042011-JFWM-026.S2). Examining the last date on which a mallard was located in Arkansas, we found no effect of sex $\left(F_{1,108}=1.64, P=0.20\right)$, year $\left(F_{2,108}=2.35\right.$, $P=0.10)$ or sex $\times$ year interaction $\left(F_{2,108}=0.71, P=\right.$ 0.49 ) on that departure date. Examining just females across all years, we found no effect of year $\left(F_{3,100}=2.19\right.$, $P=0.09)$ on the last day on which a female mallard was located in Arkansas.

After leaving Arkansas, mallards were at a location for a single duty cycle 301 times and at stopovers 105 times. The modal number of stopovers per mallard making a stopover was one. Mallards at stopovers remained there for an average of $12 \mathrm{~d}(\mathrm{SE}=0.90 \mathrm{~d}$ ) with a range from 2 to $54 \mathrm{~d}$. When we compared the counts of mallards making singles or stopovers (Table 4), we found neither a sex effect $\left(\chi^{2}=0.02, d f=1, P=0.88\right)$, year effect $\left(\chi^{2}=\right.$ $0.86, d f=2, P=0.65)$, or a sex $\times$ year effect $\left(\chi^{2}=0.80\right.$, $d f=2, P=0.67)$. However, when we tested for a year effect on the number of singles and stopovers made by females across all years, we found a year effect $\left(\chi^{2}=\right.$ $10.7, d f=3, P=0.01)$. The effect was due to the number of stopovers made in 2007. The odds of a female making a stopover as compared to a single movement in 2007 were 4 times as great as in 2004, 1.9 times as great in 2005 and 2.2 times as great as in 2006.

We recorded 19 cases (8 males, 11 females) where migrating mallards were last recorded in Arkansas and next located in the PPR. In 14 of these cases, these moves occurred over $3 \mathrm{~d}$, and in the remaining cases, these moves occurred over $4 \mathrm{~d}$. Sixteen mallards (11\%) did not migrate to the PPR. The average date of arrival in the PPR was 3 April ( $\mathrm{SE}=1.2 \mathrm{~d}, 95 \% \mathrm{Cl}=1-5$ April) with a range from 8 March to 11 May. The arrival date when a mallard
Table 4. Number of times that a mallard Anas platyrhynchos marked with satellite transmitters in Arkansas remained at a stopover or changed locations between duty cycles (single), by year and sex.

\begin{tabular}{llcc}
\hline Year & Sex & Stopover & Single \\
\hline 2004 & Female & 3 & 20 \\
& Male & 4 & 15 \\
2005 & Female & 20 & 63 \\
& Male & 11 & 40 \\
2006 & Female & 15 & 54 \\
\hline \multirow{2}{*}{2007} & Male & 8 & 38 \\
\hline \multirow{2}{*}{ Total } & Female & 44 & 71 \\
\hline
\end{tabular}

was first located in the PPR was not related to sex $\left(F_{1,95}=\right.$ $0.69, P=0.41)$, or sex $\times$ year $\left(F_{2,95}=1.69, P=0.34\right)$, but there was an effect of year $\left(F_{2,95}=4.16, P=0.02\right)$. Mallards first moved to the PPR earlier in $2006(\bar{x}=30$ March, SE $=1.86 \mathrm{~d}$ ) than in 2005 ( $\bar{x}=7$ April, SE $=1.97 \mathrm{~d}$ ). Examining just females across all years for arrival date in the PPR, we found a year effect $\left(F_{3,90}=3.55, P=0.02\right)$, but a Tukey's Honestly Significant Difference test did not indicate a difference among years. The average duration in days between being last recorded in Arkansas and next being located in the PPR was $18 \mathrm{~d}(\mathrm{SE}=1.2 \mathrm{~d})$ with a range from 3 to $76 \mathrm{~d}$. When we examined variation in this period, we found no effect of sex $\left(F_{1,93}=0.93, P=0.34\right)$, year $\left(F_{2,93}=1.97, P=0.14\right)$, or sex $\times$ year $\left(F_{2,93}=1.62, P\right.$ $=0.29$ ). Examining just females across all years, we found that the average number of days between being last in Arkansas and their entry into the PPR was affected by year $\left(F_{3,89}=9.89, P<0.001\right)$. Female spent longer on migration (Tukey's Honestly Significant Difference, $Q=$ $2.62, P<0.05)$ in $2007(\bar{x}=28 \mathrm{~d}, \mathrm{SE}=2.24 \mathrm{~d}$ ) than either during $2004(8 \mathrm{~d}, \mathrm{SE}=4.15 \mathrm{~d}), 2005(18 \mathrm{~d}, \mathrm{SE}=2.54 \mathrm{~d})$, or 2006 (13 d, SE = $2.44 d)$.

When we examined the average distance moved during each leg, we found an effect of $\operatorname{sex}\left(F_{1,194}=\right.$ $4.06, P=0.05)$, and year $\left(F_{2,194}=17.7, P<0.001\right)$, but not for sex $\times$ year $\left(F_{2,194}=0.09, P=0.91\right)$. Females moved further per leg movement $(\bar{x}=671 \mathrm{~km}, \mathrm{SE}=$ $32.0 \mathrm{~km})$ than did males $(\bar{x}=573 \mathrm{~km}, \mathrm{SE}=36.4 \mathrm{~km})$. Mallards moved further per leg movement in $2004(\bar{x}=$ $757 \mathrm{~km}, \mathrm{SE} 56.6 \mathrm{~km})$ and in $2006(\bar{x}=664 \mathrm{~km}, \mathrm{SE}=$ $34.2 \mathrm{~km})$ than in $2005(\bar{x}=446 \mathrm{~km}, \mathrm{SE}=30.2 \mathrm{~km})$. Examining this relationship for just females across all years, we found a year effect $\left(F_{3,198}=12.3, P<0.001\right)$. Female average leg movements were shorter in $2005(\bar{x}$ $=483 \mathrm{~km}, \mathrm{SE}=36.84 \mathrm{~km})$ and in $2007(\bar{x}=468 \mathrm{~km}, \mathrm{SE}$ $=31.06 \mathrm{~km})$ as compared to in $2004(\bar{x}=819 \mathrm{~km}, \mathrm{SE}=$ $75.62 \mathrm{~km})$ and in $2006(\bar{x}=712 \mathrm{~km}, 43.15 \mathrm{~km})$. When we examined the sum of the leg movements between last in Arkansas and next in the PPR, we found no effect of sex $\left(F_{1,94}=1.25, P=0.27\right)$, year $\left(F_{2,94}=0.71, P=0.49\right)$, or sex $\times$ year $\left(F_{2,94}=0.21, P=0.81\right)$. When we conducted the same test on females across all years, we found no year effect $\left(F_{3,90}=0.27 P=0.85\right)$. Mallards migrated an 


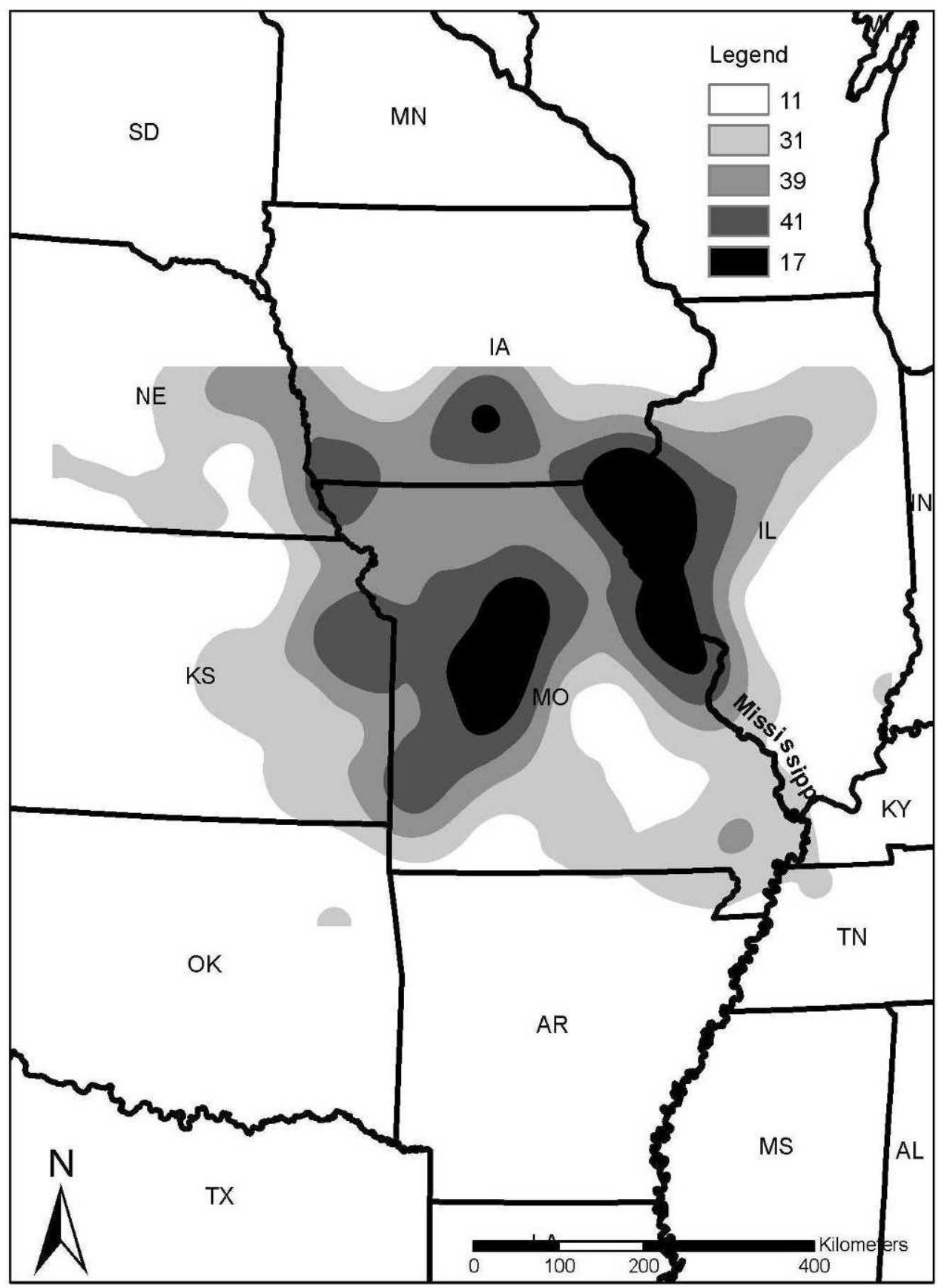

Figure 3. Kernel density estimates categorized into five classes of satellite-marked mallard Anas platyrhynchos detections, made while ducks were migrating during the spring between Arkansas and the southern latitude of the Prairie Pothole Region, North America, 2004-2007. Each shaded class contained detections from the sum of mallards that frequented any of that shaded area as well as the sum of all mallards that were detected in any of the lighter shaded areas. For example, the blank region represented 11 mallards detected there, while the lightest shaded region represented 42 mallards detected there, and so forth.

average of $1,184 \mathrm{~km}(\mathrm{SE}=25.8)$ between Arkansas and next detection in the PPR. One female mallard only migrated the minimum distance between Arkansas and the southern border of the PPR $(443 \mathrm{~km})$. At the other extreme, one female mallard migrated $2,170 \mathrm{~km}$ by first flying to southwestern Michigan and then to southwestern Manitoba in a series of five movements.

Neither temperature nor precipitation rank explained departure from Arkansas, but once mallards began migrating temperature and precipitation ranks were related to the number of stopovers made, the distance moved on each leg, the time spent on migration, and the timing of entry to the PPR. Recalling that 2007 was ranked as a much wetter and much warmer year, 2004 was ranked as a wetter and much warmer year, 2006 was ranked as a normal precipitation and much warmer year, and 2005 was ranked as a dry and warmer year, we found that 1) the number of stopovers made was 
greater in 2007 than in 2004, 2) leg movements were longer during 2004 and 2006 than in 2005, 3) the time spent on migration was longer in 2007 than in any other year, and 4) mallards entered the PPR earlier in 2006 than in 2005.

Looking first at the migration corridor between Arkansas and the southern boundary of the PPR (Figure 3), we found that mallards leaving Arkansas first made an initial migration movement over the Missouri Ozarks. In general, mallards marked to the west of the Delta migrated to central and western Missouri and eastern Kansas, where they frequented wetlands along the Chariton, Grand and Missouri Rivers in Missouri and the Marais des Cygnes, and Kansas Rivers in Kansas. These river corridors were embedded in an agricultural matrix. The mallards marked in the Delta migrated to eastern Missouri and western Illinois, again in wetlands along the Mississippi and Illinois Rivers that were embedded in an agricultural matrix. After this first migration movement, $\geq 37$ mallards moved north and west through lowa and Nebraska along the Missouri River valley into the PPR, while 53 mallards moved north into the Minnesota portion of the PPR or to the north and east of the PPR (Figure 4). Some mallards migrated as far north as the Northwest Territories (Figure 4). The state most frequented by marked mallards between Arkansas and the southern PPR was lowa (66), followed by Missouri (60), Illinois (28), Nebraska (17), Kansas (15), Indiana (2), Tennessee, (1), and Oklahoma (1).

Of those females that remained in one location for $\geq 30 \mathrm{~d}$ after entering the PPR $(n=21)$ or migrated past the southern boundary of the PPR and remained in one location for $\geq 30 \mathrm{~d}$ ( $n=11)$, these females were spread out across nine Bird Conservation Regions (BCR; $\mathrm{NABCl}$ 2011; Figure 5). The most frequented state/province where nesting occurred was South Dakota $(n=9)$. Five females nested in two different years. In four cases, females returned to the same state or province in which they nested the year before (Alberta [two], Minnesota [two]) while one female nested in Alberta in 2006 and in Saskatchewan in 2007. The average date for females apparently initiating a nest was April 19 (SE = $2.44 \mathrm{~d}$ ), with the earliest nesting on 12 March and the latest nesting on 26 May. The average length of stay at a nesting site was $135 \mathrm{~d}(\mathrm{SE}=9.6 \mathrm{~d})$ and ranged from 30 to $248 \mathrm{~d}$.

\section{Discussion}

Based on surveys from the winter grounds, mallards, along with northern pintails, are the earliest spring migrant waterfowl in North America (Bellrose 1980; Drilling et al. 2002). Departure dates for mallards are as early as late January from Arizona (Drilling et al. 2002) and most migrant mallards leave wintering areas in February and March with a sharp drop-off in April (Bellrose 1980). In Arkansas, mallard spring migration begins as early as February and continues through March, with an abrupt decline in April (James and Neal 1986). In the Arkansas Delta, wintering mallards were reported to decline in numbers by two-thirds by early
March (James and Neal 1986). Tracking a sample of VHFmarked mallards from the Arkansas Delta, Dugger (1997) reported that spring migrants began leaving Arkansas in mid-February with almost half gone by mid-March and final migrants leaving by 1 April. The Arkansas Delta was where most $(60 \%)$ of our birds were marked. Our results support those of James and Neal (1986) and Dugger (1997) because our sample of mallards migrating out of Arkansas peaked around mid-March with a noticeable drop in departures at the beginning of April.

Dugger (1997) examined three variables that could potentially explain spring migration departure date in mallards from Arkansas. He found that neither female age nor physiological condition was related to departure date, but he did find that molt status was related. He found that late-molting females migrated later than early molting females. Molt could have played a role in our mallard migration departure; however, we did not determine molt status of PTT-marked mallards.

Because of our variable duty cycles, which sometimes had up to 48-h shut-off periods, our ability to document nonstop migrations was hampered. Conditional on this technical problem, we documented 19 cases of mallards leaving Arkansas and next appearing in the PPR. Of the 31 spring-migrating northern pintails tracked with PTTs from three different wintering areas in the Central Flyway, none were documented to fly nonstop to their breeding grounds (Haukos et al. 2006). We do not think that our results were because our duty cycles were markedly different from Haukos et al. (2006) because their duty cycles ranged from $5 \mathrm{~h}$ on : $48 \mathrm{~h}$ off to $5 \mathrm{~h}$ on : $144 \mathrm{~h}$ off. Miller et al. (2005) documented springmigrating northern pintails from California's Central Valley using PTTs. They found that pintails first migrated to the region of south-central Oregon, extreme northwestern Nevada, and northeastern California, and then pintails using the "Direct Alaska" migration route apparently flew nonstop over the Pacific Ocean to Alaska, while pintails using the "Direct Canada" migration route flew nonstop overland to southern Alberta or interior British Columbia. Miller et al. (2005) further noted that the spring migration strategy used was yeardependent and apparently was related to weather conditions. It seems that spring migration timing strategies for both pintails and mallards are flexible; individuals wintering at the same sites make markedly different decisions about the pace at which they return to the breeding grounds.

Nonstop migration is a risky behavior because of the physical exhaustion, weather-related mortality, and depletion of endogenous reserves (Berthold 1996). Any one of these could negatively affect subsequent reproductive effort and productivity. To lessen the reduction of body reserves during migration, mallards must acquire sufficient reserves to make the nonstop flight. Apparently Arkansas mallards are obtaining sufficient reserves to make these nonstop flights. Positive benefits of making a nonstop flight would include the avoidance of predators at stopover sites. Miller et al. (2005) documented that half of the pintails migrating to Alaska by the coastal route were killed by 


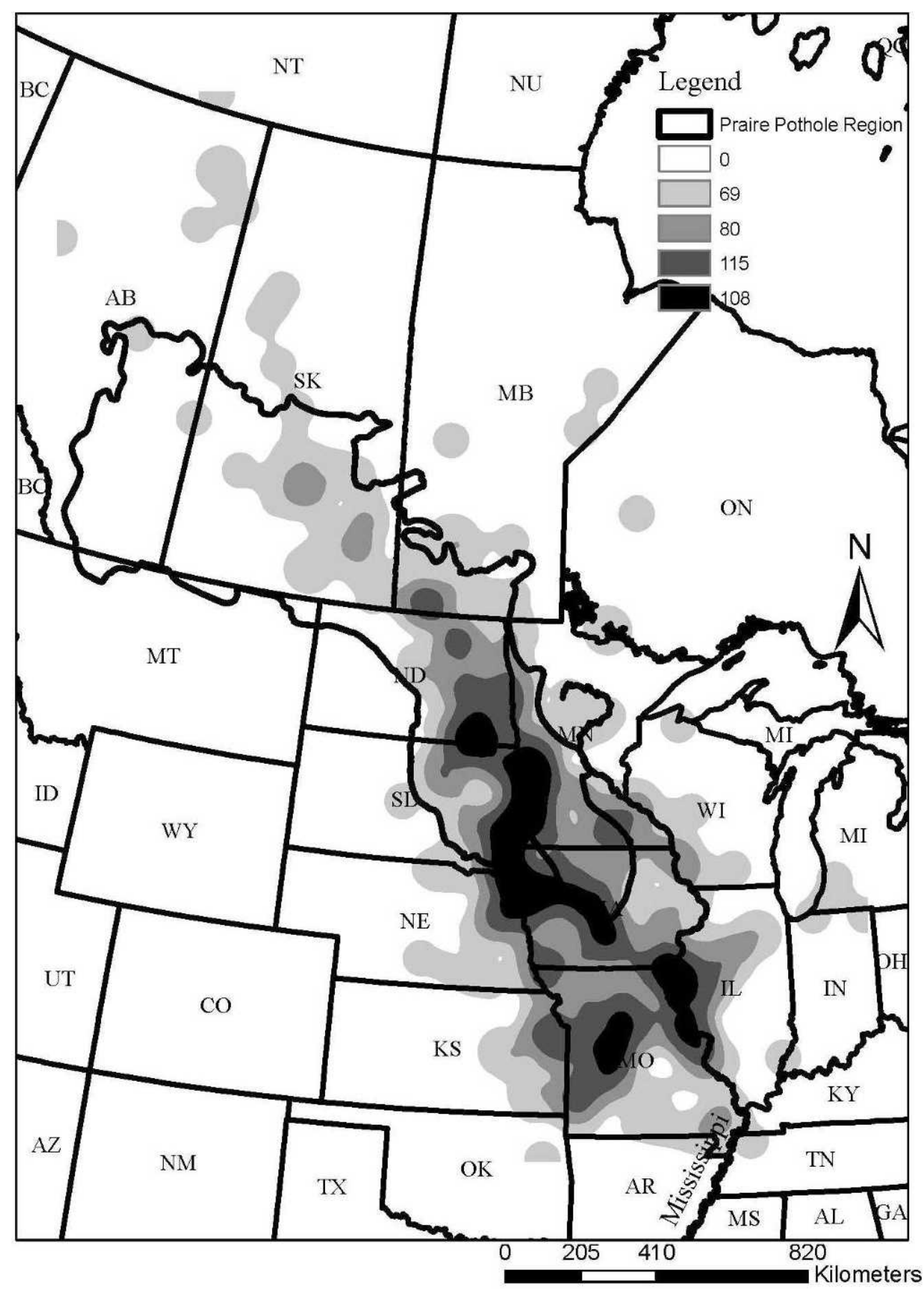

Figure 4. Kernel density estimates categorized into five classes of satellite-marked mallard Anas platyrhynchos detections, made while ducks were migrating during the spring from Arkansas, 2004-2007. Each shaded class contained detections from the sum of mallards that frequented any of that shaded area as well as the sum of all mallards that were detected in any of the lighter shaded areas. For example, the blank region represented no mallards detected there, while the lightest shaded region represented 69 mallards detected there, and so forth.

predators, while none of the pintails that migrated to Alaska nonstop over the Pacific were killed by predators.

Our observed mean arrival date in the PPR (3 April) was similar to dates found by other researchers. Most mallards arrive in the PPR beginning in late March to early April, with the peak arrival in mid-April (Bellrose 1980). Our marked mallards were spending, on average, $18 \mathrm{~d}$ on migration between Arkansas and arriving in the PPR. Because we found that the average stopover period was $12 \mathrm{~d}$, most mallards are making, on average, a single stopover during spring migration. We found annual variation in the number of stopovers; females in 2007 were 4 times as likely to make a stopover as a female in 2004, which resulted in females 


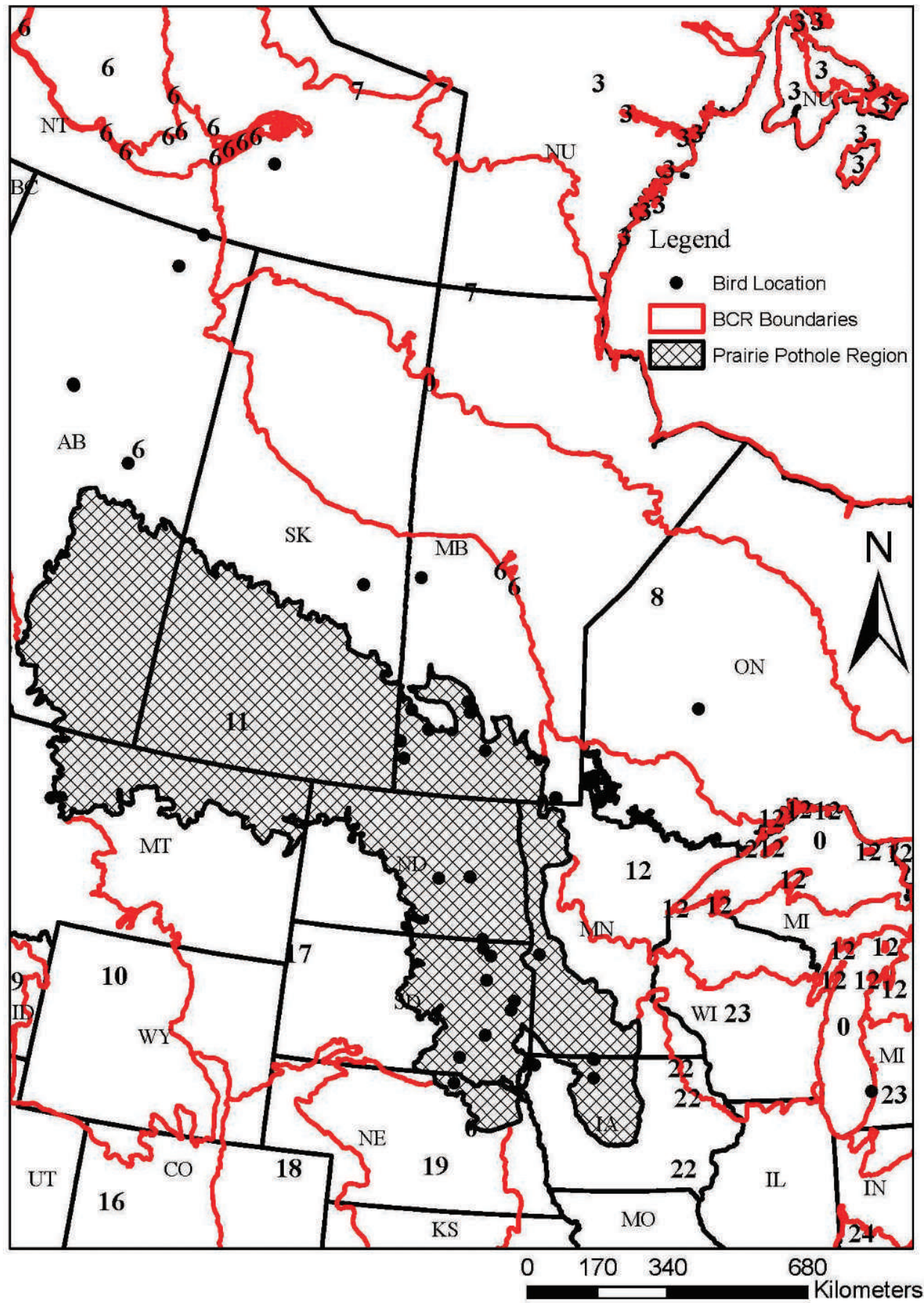

Figure 5. Locations of the probable nesting attempts by satellite-marked female mallards Anas platyrhynchos migrating during the spring from Arkansas, 2004-2007. Bird Conservation Region (BCR) codes where satellite-marked mallards nested are: $6=$ Boreal Taiga Plains, 7 = Taiga Shield and Hudson Plains, $8=$ Boreal Softwood Shield, $10=$ Northern Rockies, $11=$ Prairie Potholes, $12=$ Boreal Hardwood Transition, 19 = Central Mixed Grass Prairie, 22 = Eastern Tallgrass Prairie, and $23=$ Prairie Hardwood Transition.

taking longer to migrate in 2007 compared to 2004. The shorter migration time by females in 2004 was offset by the longest average individual leg movements $(757 \mathrm{~km})$ compared to any other year. We also found that the average leg movement by males and females were different (approx. $100 \mathrm{~km} /$ movement), yet males and females left Arkansas on the same average date and are, therefore, not always traveling together.
Evidence that males and females are not always traveling together is that the sex ratio of mallards is skewed toward males (1.33 males : 1 female during winter, [Rohwer and Anderson 1988]); thus, not all males can travel with females. Further, differential sex-specific migration rates could result from pair bonds that break and reform during spring migration (Humburg et al. 1978, Amat 2005). Pattenden and Boag (1989) docu- 
mented that female mallards will switch mates on the wintering grounds, suggesting that females test multiple males before a strong bond is established. Amat (2005) found that common teal $A$. crecca in Spain exhibited evidence of increased courtship activity during spring migration and hypothesized that this supported the idea that female teal sometimes switched mates during spring migration. Palmer (1976) also suggested that gadwalls $A$. strepera exhibited much pairing activity during spring migration even though most females were paired in late winter. Humburg et al. (1978) and Ohde et al. (1983) noted that up to $20 \%$ of male mallards arriving in central lowa during spring migration did so unpaired and these skewed sex ratios remained throughout the breeding season. Our findings of some sex-specific differences in migration patterns support the notion that if most mallards are paired when they leave the winter grounds (Drilling et al. 2002), then there may be some pair breakdown and reformation while on migration (Humburg et al. 1978; Rohwer and Anderson 1988; Drilling et al. 2002; Amat 2005).

We found no effect of weather on initiation of spring migration, but we did find that wetter conditions lengthened migration passage times. Miller et al. (2005) documented that cold-dry conditions most affected spring migration rates in pintails from California's Central Valley by delaying initiation of spring migration to the PPR and were accompanied by a movement through the PPR to Alaska when dry conditions were encountered in the PPR. There were no unusually cold years during the 4 y of our study (2004-2007). This made it difficult to compare our results with Miller et al. (2005), who found that cold conditions most affected pintails.

The migration corridors that we documented apparently represented only a single migration "strategy" as compared to the five migration strategies that Miller et al. (2005) documented for northern pintails migrating from California to their various breeding grounds. Miller et al. (2005) found that individual pintails would depart at different dates and would migrate at different rates depending on their final breeding destinations, and depending on which of the five migration strategies they used. Across the $4 \mathrm{y}$ of our study, $>75 \%$ of marked mallards from Arkansas migrated to the PPR or through the PPR to their eventual breeding destination. The origin of mallards wintering in Arkansas appears to be more focused than is the case for pintails wintering in central California.

Using our nesting criterion, we found that females were initiating nesting around April 19. This may seem early, but Bellrose (1980) and Drilling et al. (2002) reported that, across a large geographic portion of North America, mallards begin nesting between April 10 and April 30. Just south of the PPR in central lowa, Humburg et al. (1978) and Ohde et al. (1983) found mallards initiated nesting from 5 to 13 April. Based on these studies, our average nesting date is representative and suggests that the added costs of carrying the PTT did not interfere with nest initiation.

Using our nesting criteria, we found that females were nesting over a large geographic area-at least nine BCRs; granted, the most frequented $B C R$ where nesting occurred was the PPR (66\%). Hence, the PPR remains the most important BCR to nesting mallards that winter in Arkansas, as suggested by band recovery data up to the 1980s (Munro and Kimball 1982; Supplemental Material, Reference S1; http://dx.doi.org/10.3996/042011JFWM-026.S1). We also note that females nesting in BCRs to the north of the PPR (e.g., Boreal Taiga Plains, Taiga Shield and Hudson Plains, Boral Softwood Shield, $n=9$ ) all traveled through the PPR to get there. Thus, $94 \%$ of females nesting either did so in the PPR or north of the PPR. The PPR continues to be the most important BCR to nesting mallards that winter in Arkansas, which is the most important single wintering site of mallards in North America (Bellrose 1980; Munro and Kimball 1982; Supplemental Material, Reference S1; http://dx.doi.org/10. 3996/042011-JFWM-026.S1; Green and Krementz 2008).

Both we and Bellrose (1980) found two migration corridors in eastern and western Missouri that represent critical stopover and staging areas for mallards that winter in Arkansas. Migrating mallards need adequate food resources during their spring migration through these corridors if they are to arrive on the breeding grounds in good body condition, suggesting that these regions may require protection and active management. Management during wetter springs may be especially important, because we found that migration rates were slower under these conditions and required more food resources for more duck use-days. Additional research should be conducted on spring migration of mallards from Arkansas using PTT transmitters with GPS capabilities. Our PTT locations were usually of such low quality that habitats used could only be described in general. With more precise geographic locations, managers will be better able to focus wetland management strategies on exact areas of known importance.

\section{Supplemental Material}

Please note: The Journal of Fish and Wildlife Management is not responsible for the content or functionality of any supplemental material. Queries should be directed to the corresponding author.

Reference S1. Munro RE, Kimball CF. 1982. Population ecology of the mallard. VII. Distribution and derivation of the harvest. Washington, D.C.: U.S. Fish and Wildlife Service Resource Publication 147.

Found at DOI: http://dx.doi.org/10.3996/042011JFWM-026.S1 (5.56 MB PDF).

Table S1. Spring mallard Anas platyrhynchos migration data, Arkansas, 2004-2007. Bird \#, individual mallard identification number; Sex, gender of mallard; Location $(C / S)$, " $C$ " represents a stopover or a bird that remained in a single location for more than one duty cycle, " $S$ " represents a bird that remained in a single location for one duty cycle; First Day, the Julian Day when the bird was first at a particular location; Last Day, the Julian Day when the bird was last at the First Day location; Duration (days), the sum total of days that a bird was at a particular location ( 0 represents a bird at a location for $1 \mathrm{~d}$ ); Start Migration, the Julian Day when a 
bird was first detected outside of Arkansas; Cal_Start Date, the calendar date when a bird was first detected outside of Arkansas; Enter PPR, the Julian Day when a bird was first detected in the Prairie Pothole Region; Migration duration, the sum total Julian Days between when the bird was first detected outside of Arkansas and first arrived in the PPR; Year, calendar year; Location code, the Bird Conservation Region number where the bird was located when it stopped for $\geq 30 \mathrm{~d}$ either in the Prairie Pothole Region or north of the southern boundary of the Prairie Pothole Region (approx. $\mathrm{N} 41^{\circ} 15^{\prime}$ ); From, the beginning Julian Day of a migration movement; To, the end Julian Day of a migration movement; Distances, the distance $(\mathrm{km})$ traveled between the beginning and end locations; Bearing, the straight-line compass bearing between the beginning and end locations; End Distances, the distance ( $\mathrm{km})$ traveled between the departure from Arkansas and the end of migration; End Bearing, the straight-line compass bearing between the departure from Arkansas and the end of migration.

Found at DOI: http://dx.doi.org/10.3996/042011JFWM-026.S2 (57 KB XLSX).

\section{Acknowledgments}

We thank all the biologists who helped capture mallards in Arkansas, H. Ford for logistical support, and R. Reynolds for his input on various aspects of mallard biology. We thank J. Wilson and B. Culpepper of the Center for Advanced Spatial Technologies at the University of Arkansas for prescreening the Argos data. We thank A. Raedeke, J. Tirpak, P. Flint, M. Eichholz, S. Oldenburger, one anonymous reviewer, and the Subject Editor, D. Haukos, for commenting on an earlier version of this manuscript.

Funding was provided by the Arkansas Game \& Fish Commission and the U.S. Geological Survey Arkansas Cooperative Fish and Wildlife Research Unit.

The use of trade, product, industry or firm names or products is for informative purposes only and does not constitute an endorsement by the U.S. Government or the U.S. Geological Survey.

\section{References}

Alisauskas RT, Ankney CD. 1992. The cost of egg laying and its relationship to nutrient reserves in waterfowl. Pages 30-61 in Batt BDJ, Afton AD, Anderson MG, Ankney CD, Johnson DH, Kadlec JA, Krapu GL, editors. Ecology and management of breeding waterfowl. Minneapolis: University of Minnesota Press.

Amat JA. 2005 Should females of migratory dabbling ducks switch mates between wintering and breeding sites? Journal of Ethology 24:297-300.

Arnold TW, Howerter DW, Devries JH, Joynt BL, Emery RB, Anderson MG. 2002. Continuous laying and clutch-size limitation in mallards. Auk 119:261-266.

Bellrose FC. 1980. Ducks, geese, and swans of North America. 3rd edition. Harrisburg, Pennsylvania: Stackpole.
Bellrose FC, Scott TG, Hawkins AS, Low JB. 1961. Sex ratios and age ratios in North American ducks. Illinois Natural History Survey Bulletin 27:391-474.

Berthold P. 1996. Control of bird migration. London: Chapman and Hall.

[CLS] Collecte Localisation Satellites. 2008. Argos user's manual. Toulouse, France: CLS. Available: http://www. argos-system.org/?nocache $=0.7343113972301377$ (November 2009).

de Solla SR, Bonduriansky R, Brooks RJ. 1999. Eliminating autocorrelation reduces biological relevance of home range estimates. Journal of Animal Ecology 68:221234.

Devries JH, Brook RW, Howerter DW, Anderson MG. 2008. Effects of spring body condition and age on reproduction in mallards (Anas platyrhynchos). The Auk 125:618-628.

Drilling N, Titman R, McKinney F. 2002. Mallard (Anas platyrhynchos). Account 658 in Poole A, Gill F, editors. The birds of North America. Philadelphia, Pennsylvania: The Academy of Natural Sciences; and Washington, D.C.: The American Ornithologists' Union.

Dubovsky JA, Kaminski RM. 1994. Potential reproductive consequences of winter-diet restriction in mallards. Journal of Wildlife Management 58:780-786.

Dugger BD. 1997. Factors influencing the onset of spring migration in mallards. Journal of Field Ornithology 68: 331-337.

Evrard JO, Bacon BR. 1998. Duck trapping success and mortality using four trap designs. North American Bird Bander 23:110-114.

Farmer AH, Wiens JA. 1999. Models and reality: timeenergy trade-offs in pectoral sandpiper (Calidris melanotos) migration. Ecology 80:2566-2580.

[GAP] Gap Analysis Program/[LULC] Land Use Land Cover. 2007. Available: http://www.ar.nrcs.usda.gov/ soils/land_use.html (June 2011).

Green AW, Krementz DG. 2008. Mallard harvest distributions in the Mississippi and Central Flyways. Journal of Wildlife Management 72:1328-1334.

Haukos DA, Miller MR, Orthmeyer DL, Takekawa JY, Fleskes JP, Casazza ML, Perry WM, Moon JA. 2006. Spring migration of northern pintails from Texas and New Mexico, USA. Waterbirds 29:127-136.

Heitmeyer ME, Fredrickson LH. 1981. Do wetlands conditions in the Mississippi delta hardwoods influence mallard recruitment? Transactions of the North American Wildlife and Natural Resources Conference 46:44-57.

Humburg DD, Prince HH, Bishop RA. 1978. The social organization of a mallard population in northern lowa. Journal of Wildlife Management 42:72-80.

James DA, Neal JC. 1986. Arkansas birds their distribution and abundance. Fayetteville: The University of Arkansas Press.

Jenks GF. 1967. The data model concept in statistical mapping. International Yearbook of Cartography 7: 186-190. 
Johnson FA, Moore CT, Kendall WL, Dubovsky JA, Caithamer DF, Kelley JR, Williams BK. 1997. Uncertainty and the management of mallard harvests. Journal of Wildlife Management 61:202-216.

[JV] Upper Mississippi River and Great Lakes Joint Venture. 2007. Upper Mississippi River and Great Lakes Region Joint Venture Implementation Plan. Available: http://www. uppermissgreatlakesjv.org/docs/JV2007All-BirdPlanFinal211-08.pdf (September 2011).

Kaminski RM, Gluesing EA. 1987. Density- and habitatrelated recruitment in mallards. Journal of Wildlife Management 51:141-148.

Kenow KP, Meyer MW, Evers DC, Douglas DC, Hines J. 2002. Use of satellite telemetry to identify common loon migration routes, staging areas and wintering range. Waterbirds 25:449-458.

Krapu GL. 1981. The role of nutrient reserves in mallard reproduction. The Auk 98:29-38.

Malecki RA, Batt BDJ, Sheaffer SE. 2001. Spatial and temporal distribution of Atlantic population Canada geese. Journal of Wildlife Management 65:242-247.

Mann GE. 1974. The prairie pothole region-a zone of environmental opportunity. Naturalist 25:2-7 [map].

McIntyre CL, Douglas DC, Collopy MW. 2008. Movements of golden eagles (Aquila chrysaetos) from interior Alaska during their first year of independence. The Auk 125:214-224.

Miller RM, Takekawa JY, Fleskes JP, Orthmeyer DL, Casazza ML, Perry WM. 2005. Spring migration of northern pintails from California's Central Valley wintering area tracked with satellite telemetry: routes, timing and destinations. Canadian Journal of Zoology 83:1314-1332.

Munro RE, Kimball CF. 1982. Population ecology of the mallard. VII. Distribution and derivation of the harvest. Washington, D.C.: U.S. Fish and Wildlife Service Resource Publication 147 (see Supplemental Material, Reference S1; http://dx.doi.org/10.3996/042011-JFWM026.S1).

[NCDC] National Climatic Data Center. 2011. U.S. climate at a glance. Available: http://www.ncdc.noaa.gov/oa/ climate/research/cag3/cag3.html (July 2011).

[NABCl] North American Bird Conservation Initiative United States. 2010. Bird Conservation regions. Available: http://www.nabci-us.org/bcrs.htm (February 2011).

North American Waterfowl Management Plan Assessment Steering Committee. 2007. North American Waterfowl Management Plan, Continental Progress Assessment, Final Report. Available: http://www.fws. gov/birdhabitat/NAWMP/files/FinalAssessmentReport. pdf (September 2011).
Ohde BR, Bishop RA, Dinsmore JJ. 1983. Mallard reproduction in relation to sex ratios. Journal of Wildlife Management 47:118-126.

Palmer RS, editor. 1976. Handbook of North American birds. Volume 2: waterfowl (first part). New Haven, Connecticut: Yale University Press.

Pattenden RK, Boag DA. 1989. Effects of body mass on courtship, pairing, and reproduction in captive mallards. Canadian Journal of Zoology 67:495-501.

Petrie S, Rogers KH, Baloyi FR. 1996. Effects of harnessattached satellite transmitters on captive white-faced ducks Dendrocygna viduata. South African Journal of Wildlife Research 26:93-95.

Raveling DG, Heitmeyer ME. 1989. Relationships of population size and recruitment of pintails to habitat conditions and harvest. Journal of Wildlife Management 57:1088-1103.

Rohwer RC, Anderson MG. 1988. Female-biased philopatry, monogamy, and the timing of pair formation in migratory waterfowl. Current Ornithology 5:187-221.

Roshier DA, Asmus MW. 2009. Use of satellite telemetry on small-bodied waterfowl in Australia. Marine and Freshwater Research 60:299-305.

SAS Institute. 2010. JMP. Cary, North Carolina: SAS Institute, Inc.

Seaman DE, Millspaugh JJ, Kernohan BJ, Brunidge GC, Raedeke KJ, Gitzen RA. 1999. Effects of sample size on kernel home range estimates. Journal of Wildlife Management 63:739-747.

Seaman DE, Powell RA. 1996. An evaluation of the accuracy of kernel density estimators for home range analysis. Ecology 77:2075-2085.

Sparrowe RD, Patterson JH. 1987. Conclusions and recommendations from studies under stabilized duck hunting regulations: management implications and future directions. Transactions of the North American Wildlife and Natural Resource Conference 52:320-326.

Swihart RK, Slade NA. 1997. On testing for independence of animal movements. Journal of Agricultural, Biological, and Environmental Statistics 2:48-63.

Worton BJ. 1989. Kernel methods for estimating the utilization distribution in home-range studies. Ecology 70:164-168.

Wunz GA. 1984. Rocket net innovations for capturing wild turkeys and waterfowl. Transactions of the Northeast Section of the Wildlife Society 41:219.

Yamaguchi N, Hiraoka E, Fujita M, Hijikata N, Ueta M, Takagi K, Konno S, Okuyama M, Watanabe Y, Osa Y, Morishita E, Tokita K, Umada K, Fujita G, Higuchi H. 2008. Spring migration routes of mallards (Anas platyrhynchos) that winter in Japan, determined from satellite telemetry. Zoological Science 25:875-881. 